\title{
Geological mapping of the Late Cretaceous Chalk Group of southern England: a specialised application of landform interpretation
}

\author{
Don T Aldiss*, Andrew R Farrant and Peter M Hopson \\ British Geological Survey, Keyworth, Nottingham, NG12 5GG, UK \\ *Corresponding author (e-mail: dta@bgs.ac.uk)
}

Telephone: 01159363129

Fax: 01159363200

Running title: Geological mapping of the Chalk Group

\begin{abstract}
The modern Chalk Group lithostratigraphy divides the Chalk of southern England into nine formations, each with a characteristic lithological assemblage. It is more useful than the traditional subdivision into Lower Chalk, Middle Chalk and Upper Chalk because it can be applied more consistently over a wider area, it provides a better indication of lithological variation, it allows the recognition of more tectonic structures and it is thus more useful for practical application in engineering geology and hydrogeology.
\end{abstract}

The process of surveying the Chalk that has been developed by the British Geological Survey over the past two decades is an empirical modification of the traditional methods used for detailed geological survey of sedimentary sequences in other parts of the United Kingdom. Each Chalk formation is closely associated with characteristic landforms, allowing them to be mapped with reasonable consistency and accuracy in largely unexposed ground and through built-up areas. This association of landform and lithostratigraphy reflects the response to weathering (and other surface processes) of relatively subtle variations in bulk lithological assemblage, rather than of individual beds of contrasting lithology.

End (179 words)

Keywords: Late Cretaceous; Chalk; geological mapping; geomorphology; England 


\section{Introduction}

The Late Cretaceous Chalk Group crops out extensively in southern and eastern England, where it varies between about 200 and $560 \mathrm{~m}$ in total thickness (Figure 1), reflecting both variation in stratal thickness and in the extent of post-Cretaceous erosion. The composition of the Chalk is relatively uniform, mainly comprising fairly pure fine-grained microporous limestones, although with important variations in clay content, hardness, texture, fossil content and occurrence of flint. These variations in composition - together with a knowledge of local tectonic structure - are very important factors in the understanding of the engineering and hydrogeological properties of the Chalk (Mortimore et al., 1990; Mortimore, 1993; Warren and Mortimore, 2003; Mortimore et al., 2011), in addition to their relevance to stratigraphic and sedimentological research (Gale, 1996; Gale et al., 1999; Gale et al., 2002; Hopson, 2005; Mortimore, 2011a).

The Chalk forms ranges of hills that are traversed by numerous transportation routes and it lies within the zone of human interaction beneath some densely populated parts of the southeast of England, including the megacity of London. It is the most important British aquifer in terms of yield and size of dependent population, yet it is particularly vulnerable to contamination (Headworth et al., 1980; Foster, 1993). An understanding of the engineering and hydrological properties of the Chalk, and of their spatial variation, is essential for infrastructural development and maintenance, and for water resource management. It is therefore important that accurate, detailed geological maps of the Chalk outcrop are available. An understanding of the methods used to construct maps of the Chalk can provide a better appreciation of the meaning, uses and limitations of those maps.

This paper contrasts historical practice in mapping the Chalk with the application of a lithostratigraphic scheme developed during the 1990s (Bristow et al., 1997; Mortimore et al., 2001; Hopson, 2005; Table 1) and since used widely in southern and eastern England by the British Geological Survey (BGS). It explains why this new scheme was introduced and describes how the new chalk formations are recognised and geologically surveyed in the field. It complements and refines the initial account by Bristow et al. (1997), which was based largely on the findings of field surveys in Dorset and Sussex, and which noted that the 'lateral continuity of mappable features and their relationship to lithostratigraphy will continue to be tested as mapping extends ...'.

This new scheme has enabled BGS to convey more detailed information about the composition and structure of the Chalk on their geological maps (and, more recently, in their digital three-dimensional geological models), which are therefore expected to be of more practical value, particularly for engineering geologists and hydrogeologists. Some other factors, such as Cenozoic landscape evolution, the history of groundwater distribution and of karst development, are also important influences on the applied geology of the Chalk but these are largely beyond the scope of this paper.

\section{The traditional subdivisions of the English Chalk and their associated problems}

Traditionally, geological maps of the English Chalk have shown three divisions, corresponding to the recognised broad variations in abundance of flint: the Lower Chalk, the Middle Chalk and the Upper Chalk (Jukes-Browne and Hill, 1903; 1904; Table 1). These were first mapped systematically in the Chiltern Hills, where their limits can be mapped consistently and accurately by tracing the position of two very characteristic marker beds: the Chalk Rock, at the base of the Upper Chalk, and the Melbourn Rock, at the base of the Middle Chalk (Jukes-Browne, 1880; Hill and Jukes-Browne, 1886). Both these markers can be readily recognised at exposure and from rock fragments ('brash') in the soil. 
This method of sub-dividing the Chalk by tracing marker beds was used by the Geological Survey for more than a century, most recently in Hertfordshire in 1992 (Hopson et al., 1996). These traditional divisions became familiar to all those who used geological maps depicting the Chalk. Unfortunately, there are several problems with this practice and, generally speaking, the further away from the Chilterns one goes, the worse these problems become.

There are three types of problem encountered in attempting to map the old Lower, Middle and Upper Chalk units. Firstly, the markers traditionally used to subdivide the Chalk are impersistent. The Melbourn Rock can be traced throughout southern England but does not continue north of the Wash (Mortimore et al., 2001). The Chalk Rock is a condensed succession, including some characteristic mineralised hardgrounds, that is generally less than $5 \mathrm{~m}$ thick and confined to the western parts of the Chalk of southern England (Bromley and Gale, 1982; Figure 1). It is absent in the more expanded successions of the North Downs and the South Downs. In the North Downs, where the equivalent interval is represented by perhaps as much as $40 \mathrm{~m}$ of strata, the base of the Upper Chalk was generally defined by BGS surveyors as the base of the plana Zone (Table 1), but this horizon may be difficult to recognise in the field, and in practice it was taken at the first appearance of the 'reussianum fauna' (Gallois, 1965) or at a thin succession of closely spaced marl seams associated with large, nodular flints known as the 'Basal Complex' (Smart et al., 1966; Mortimore and Wood, 1986; Mortimore et al., 2001). In the South Downs, however, no mappable proxy for the Chalk Rock could be found and the Upper Chalk was not separated from the Middle Chalk (Young and Lake, 1988).

Secondly, each traditional subdivision of the Chalk shows significant vertical variation in composition. The lower part of the Lower Chalk is everywhere in 'chalk marl' facies, characterised by a rhythmic alternation between beds of soft, clay-rich, marly chalk and of hard limestone. This alternation is not apparent in most of the upper part of the Lower Chalk, sometimes known as the Grey Chalk. The Grey Chalk typically comprises fairly massively bedded chalks with a lesser average clay content and more uniform composition than the Chalk Marl.

Vertical compositional variation is even more marked in the Middle Chalk, where much of the chalk of the lower part (including the Melbourn Rock) is hard (some very hard) and commonly nodular, but usually flint-free, with numerous beds with abundant fossil shell debris, whereas the upper part is typically uniformly textured, less hard, with sparse fossil remains and sparse flints.

A similar contrast is found in the Upper Chalk. A significant lower portion is everywhere characterised by notably hard, grainy chalks, many of which are nodular. Hardgrounds, such as those of the Chalk Rock, are commonly present and widely developed. The greater part of the Upper Chalk, however, is dominated by smooth-textured, relatively soft chalks in which hardgrounds and hard, grainy chalks occur only sporadically and locally. Other significant systematic variations occur within this upper part of the Upper Chalk: in the frequency and type of flint nodules, in the abundance and type of fossil debris and in the frequency of occurrence of 'marl seams'. Marl seams are thin beds of clay-rich chalk. They are typically less than $10 \mathrm{~mm}$ in thickness but many form very persistent marker beds, some of which are traceable over hundreds of kilometres (Wray, 1999; Mortimore et al., 2001). Although marl seams may comprise only a small percentage of the rock mass, they have a marked influence on its permeability and fracture style (Mortimore et al., 1990; Mortimore, 2011a).

Thirdly, the traditional subdivisions of the Chalk are thick: the Lower Chalk varies from about 45 to $90 \mathrm{~m}$; the Middle Chalk from 35 to $100 \mathrm{~m}$, and the Upper Chalk up to at least $400 \mathrm{~m}$ in parts of Hampshire and Sussex. This means that in most areas the outcrops of each 
unit are broad, and that some tectonic structures are not revealed by geological survey. For example, although a faulted displacement of one of the traditional markers might be observed, or suspected, it is usual that the orientation of the fault (or its very existence) cannot be demonstrated by tracing its outcrop to the next marker, as illustrated by Hopson et al. (1996, fig. 32), for example. In an extreme case, the Chalk downs of Hampshire and Wiltshire were previously shown on published medium-scale geological maps as an undivided outcrop of Upper Chalk more than $25 \mathrm{~km}$ across (Figure 2a). Little indication was given of the structure in this area. Modern mapping using the new Chalk stratigraphy clearly picks out the structure and is more informative to the map user (Figure 2b) (Booth, 2002).

Similarly, mapping of the new stratigraphy within the Chalk of the Salisbury district led to recognition of the full extent of the Mere Fault zone and allied structures and enabled their accurate delineation for the first time (Figures 2c and 2d) (Chadwick, 1993, figs. 9 and 10; Hopson et al., 2007). Likewise, modern mapping of the Chalk in the Isle of Wight has demonstrated the geological structure of the Central Downs (Farrant et al., 2012).

Indeed, the value of mapping thinner subdivisions of the Chalk had already been demonstrated by Brydone (1912, 1942) in Hampshire and by Gaster (1937, 1939, 1944, 1951 ) in Sussex, whose maps show many tectonic structures that have appeared only on the recently revised editions of the corresponding BGS geological maps. Brydone's and Gaster's maps nominally depict the distribution of biozones, rather than lithostratigraphic units: this is discussed in Section 4.2.2.

\section{Modern lithostratigraphic subdivision of the Chalk Group}

In the light of these problems, during the early 1990s it was decided to attempt to subdivide the Chalk in a new way, combining a new lithostratigraphic approach to the Chalk with an adaption of the landform mapping methods used by the BGS in other poorly exposed areas of England. This led to the development of a generalised lithostratigraphic scheme (Bristow et al., 1997), following in particular the work of Mortimore (1986) and of Bristow et al. (1995), that has been refined and ratified by the Geological Society Stratigraphical Commission (Hopson, 2005; Table 1). Subsequent BGS mapping has shown that this scheme is valid throughout southern England, and to date it has been applied to most of the Chalk outcrop south of the Wash.

A different lithostratigraphic scheme had already been applied to the Chalk of Lincolnshire and Yorkshire, north of the Wash. Although there were prolonged attempts to impose the traditional tripartite division of the Chalk in that region, these proved to be 'inconsistent and erratic' (Wood and Smith, 1978). Instead it has been divided into five formations different to those found in the south of England: four mappable units defined by Wood and Smith (1978), together with the uppermost Rowe Formation (Table 1). The latter was defined in offshore successions (Lott and Knox, 1994) but was later recognised from borehole records in coastal east Yorkshire, where it is everywhere obscured beneath Quaternary deposits (or 'drift') (Sumbler, 1999). Wood and Smith (1978, p.268) stated 'it is an important aspect of the proposed classification that the formation boundaries are mappable - i.e. traceable over the drift-free outcrop without the benefit of exposures.'

South of the Wash, geological mapping of the Chalk is no longer based on the tracing of marker beds, but instead on tracing boundaries between formations distinguished by their bulk rock mass character (Table 2). Even though there is a good deal of compositional variation within some of the new units, some overlap in composition between them, and some of the boundaries are gradational, the new Chalk formations are a better reflection of the variations in composition than are the traditional subdivisions. The apparently subtle 
lithological differences between the formations give rise to observable contrasts in the field that can be mapped consistently across country during relatively rapid field surveys, in accord with the criterion of 'mappability' described by Wood and Smith (1978).

Each of the new divisions is significantly thinner than the old ones (Table 2), so the outcrops are narrower and there is more scope to recognise and map tectonic structures. Even so, the units are still relatively thick, compared with many formations mapped in Lower Cretaceous or Jurassic successions, for example. Finer subdivisions and numerous marker beds can be recognised in exposures (Mortimore, 1986; Mortimore, 2011a, and references therein) and in geophysical borehole logs (Barker et al., 1984; Murray, 1986; Woods and Aldiss, 2004; Woods, 2006). However, although it might be possible to map some of these subdivisions locally, the new formations are considered to be the current practical limit of subdivision of the Chalk for routine regional geological survey purposes.

\section{Geological mapping methods in the Chalk}

\subsection{Application of general mapping methods in poorly exposed terrain}

Geological field mapping relies partly on direct observation of the geological units, either in exposures or in boreholes, and partly on indirect observation, through the expression of the local geology in landforms, soil composition and vegetation.

In many parts of England, geological exposures are limited to situations such as quarries, road and rail cuttings, unpaved track-beds, coastal sections, animal burrows or the roots of fallen trees. Even in the most favourable circumstances, exposures that define the position of Chalk formation boundaries sufficiently precisely for large-scale geological mapping are rarely seen inland, perhaps only one in $50 \mathrm{~km}^{2}$ on average. Some Chalk formation boundaries are hardly ever exposed at the surface, perhaps only once in more than $100 \mathrm{~km}$ of outcrop length.

Hand auger sampling is used routinely for geological surveying in lowland Britain, but on the Chalk it is unsatisfactory, both because much chalk and flint is too hard to sample by auger and because the natural fabric of the Chalk is usually too disturbed by augering for reliable assessment. Augering is normally of use to field survey of the Chalk only where mapping the base of the group, where the bedrock strata tend to be clay-rich and relatively soft, although in many areas the basal contact is commonly covered by superficial deposits that are too thick or too gravelly to be penetrated with a hand auger.

It is possible to model subsurface formation boundaries in the Chalk given an appropriate distribution of boreholes, and from such a model one may be able to predict surface outcrop patterns. In practice, however, subsurface data very rarely yields a modelled outcrop pattern that is sufficiently reliable to show on a large-scale geological map. In the Chalk of the Berkshire Downs, for example, there is a relatively high density of boreholes for which either core samples or geophysical logs are available. Even so, boreholes in which the position of the Melbourn Rock (the marker most frequently identified in boreholes) can be reliably identified are no more densely distributed than one in $5 \mathrm{~km}^{2}$, and for most other stratigraphic markers the density is much less.

In short, it is not possible to make a sufficiently reliable map of the Chalk using direct observation alone.

Two types of indirect observation are commonly used in large-scale geological survey in England: observation of rock fragments in the soil (known as 'brash'), and observation of landforms (Barnes, 1981; Moseley, 1981; Powell, 1993). 
Care in assessing brash needs to be taken, as individual rock fragments can be transported considerable distances by slope processes, and by agricultural work, and the presence of only a few fragments does not necessarily demonstrate that the parent bedrock underlies the site. Nevertheless, experience shows that the occurrence of rock fragments, especially where these occur in concentration, commonly can provide a reliable proxy of outcrop extent. In some places, the brash generated by present ploughing methods is so fresh and voluminous that it is almost as good as exposure, particularly when having been exposed to rain.

It is widely understood that many landforms reflect the composition of the underlying geological formations. Resistant units are more likely to underlie topographic prominences while easily-erodible lithologies tend to underlie low-lying ground. These principles are reflected by the general development of 'scarp-and-vale' scenery over the sedimentary bedrock over much of central and southern Britain (for example, Goudie, 1990). Although systematic investigations of this relationship seem to be rarely described in the literature, Belt and Paxton (2005) have confirmed the principles using quantitative GIS techniques. The same principles are well-established in the geological interpretation of aerial photographs (Allum, 1966; Moseley, 1981; van Zuidam, 1985), aspects of which are analogous to landform interpretation processes employed in geological field survey of poorly exposed terrain.

The same processes that generate the broad scarp-and-vale topography also generate more subtle, smaller-scale topographic features. The experience of BGS geological surveyors shows that careful scrutiny of landforms can provide a remarkable level of detail in geological mapping. In regularly-bedded successions with a strong lithological contrast (such as the sandstone-mudstone successions of the English Carboniferous Coal Measures, or the limestone-mudstone successions in the English Jurassic), given favourable circumstances it is possible to map individual hard beds significantly less than 1 metre in thickness. Fault displacements of as little as 1 metre can be demonstrated in unexposed ground (Brandon et al., 1990; Berridge et al., 1999).

\subsection{An empirical mapping method for the modern Chalk formations}

The geological mapping techniques used on bedrock successions characterised by strongly contrasting lithologies, such as the Coal Measures (Powell, 1993), are not directly applicable to the Chalk, where lithological contrasts tend to be more subtle. It has therefore been necessary to adopt an empirical approach to mapping the Chalk, by determining the particular landforms that are associated with the changes in bulk composition that characterise each formation. Once the relationship between landforms and the underlying geology is understood, the landforms can provide the means of tracing geological boundaries consistently and accurately over large distances in unexposed terrain, albeit usually only semi-continuously. Whereas examination of brash is mostly of use only in arable fields, the landforms associated with a particular geological unit can commonly be recognised irrespective of land use and in many cases can be traced through built-up areas.

\subsubsection{Topographical expression of Chalk formations}

The relationship between individual Chalk formations and topographic landforms can be seen on topographic profiles through typical segments of the Chalk escarpment (Figure 3). By convention, an upward decrease in gradient is described as a positive break of slope, if it is relatively sudden (as usually found at the base of the Lewes Nodular Chalk, for example), or as a convex slope, if more gradual. Conversely, a concave slope displays a gradual upward increase in gradient and an abrupt upward increase in gradient is described as a negative break of slope, as typically found to mark the contact between the Holywell Nodular Chalk 
and the New Pit Chalk (Figures 3, 4 and 5). In addition to breaks of slope that mark the formation boundaries, each Chalk formation tends to have a characteristic slope profile. For example, the outcrop of the New Pit Chalk usually forms a very uniform slope in the steepest part of the escarpment. By contrast, the Seaford Chalk in particular is often associated with the classic smooth rounded convex slopes of English downland. The characteristic landforms associated with each of the Chalk formations are described further below.

Slope evolution in a mature Chalk escarpment might be supposed to be controlled by superficial weathering and mass-movement processes, leading to the development of an erosional ('rounded-off') convex upper slope and a depositional concave lower slope (Goudie, 1990, p. 197). While it is clear that in some places the Chalk is indeed obscured by accumulations of solifluction deposits (e.g. Kerney et al., 1964; Catt and Hodgson, 1976), in large parts of the outcrop there are topographic features that do correspond to bedrock layers. This correspondence can be demonstrated by a consistent association with a change in lithological assemblage, or where the mapped extent of a topographic feature conforms to the expected shape of a bedrock outcrop pattern. Not all topographic features of this type correspond to formation boundaries, but may nevertheless appear consistently at a certain horizon within a formation. The topographic features can be most precisely located in the field but can also be mapped to some extent and to varying degrees of precision by reference to large-scale contour maps, or aerial photographs viewed stereoscopically, or digital terrain models.

Some of the landforms used in Chalk mapping are relatively abrupt and obvious changes in slope angle, whose ground position can be identified with reasonable certainty. In other instances, a geological boundary might appear initially to lie within a broad concave slope but close examination (perhaps requiring the surveyor to crouch or adopt a prone position) shows that in reality the slope is not truly curved but comprises several planar elements separated by subtle but clearly-defined breaks of slope. Clark (1965, quoted by Goudie, 1990, p.191) carried out a quantitative survey of slopes in English Chalk terrain. He found that only about 32 per cent of his measured profiles had the simple convexo-concave form commonly perceived as 'usual' for Chalk downland, and that segments with a uniform (or 'straight') slope are common. In some cases, however, a geological surveyor might be required to identify a line of maximum curvature within a truly curved slope.

The correlation of a particular topographic feature with a Chalk formation boundary can, in rare cases, be demonstrated where the feature runs into an exposure, such as a quarry. Usually, however, it depends on assessment of the brash either side of the feature, normally by inspecting freshly broken rock fragments with a hand lens.

Characteristic types or assemblages of chalk and flint, including their fossil content, observed in brash can commonly be used to locate their stratigraphic position quite accurately (Table 3), particularly when considered in the context of observations from the surrounding area. Commonly, where such markers occur within Chalk formations they serve as a valuable guide to the relative proximity of the formation boundaries.

\subsubsection{Palaeontological mapping criteria}

Fossil material in the Chalk can be treated in both a lithostratigraphical and a biostratigraphical sense. Both approaches are extremely useful, not least because many Chalk palaeofaunas are dominated by the remains of benthic organisms and so there is commonly a close relationship between the different lithological assemblages in the Chalk and its biostratigraphical zones (e.g. Smart et al., 1966) (Table 1). (Many of the fossils found in the Chalk are illustrated by Mortimore et al., 2001, Smith and Batten, 2002, and Mortimore, 
2011a). Also, the chalk lithology partly reflects its microscopic bioclastic components. The grainy textures of many chalks, especially in the Lewes Nodular Chalk and the Holywell Nodular Chalk, in large part reflect a concentration of minute calcite prisms derived by the comminution of inoceramid bivalve shells. Studies by scanning electron microscope has shown that other chalks are dominated by coccoliths, or calcispheres or other types of microfossil material (Hancock, 1975; Mortimore et al., 2001).

Both macrofossils and microfossils are used biostratigraphically, and provide valuable support to local geological interpretation, and correlation of landforms. For example, the base of the Newhaven Chalk is defined (Bristow et al., 1997; Hopson, 2005) by the incoming of common marl seams above the flinty marl-free chalks of the Seaford Chalk. However, when surveying inland chalk outcrops, marl seams are very rarely seen, except in the larger quarries, and certainly cannot be mapped by direct observation. Therefore, in order to map a consistent horizon, the base of the $U$. socialis Zone is accepted as a proxy for the base of the Newhaven Chalk. This might appear to replace lithostratigraphic with biostratigraphical criteria. In practice, however, what is actually observed in the field is the incoming of a particular assemblage of bioclastic debris (mainly comprising indeterminate crinoid brachials, asteroid plates and thin-shelled oysters, but including calyx plates of $U$. socialis), together with changes in the type and abundance of chalk and flint fragments in the soil (especially in ploughed fields). In short, the zone fossil is treated just as one of the components of the whole rock, and the field location of the base of the socialis Zone can thus be inferred from lithostratigraphic evidence.

This illustrates the point that, in general, biozonal boundaries cannot be mapped directly by field observation; in the field they can be traced only by reference to some lithostratigraphic marker that serves as a proxy. Although the published maps by Brydone $(1912,1942)$ and Gaster (1937, 1939, 1944, 1951) nominally show biozonal boundaries, it can be argued that these maps were derived by tracing landforms and so are essentially lithostratigraphic in nature. As pointed out by Woods et al. (2002), field observations of macrofossils (in either exposure or brash) are too widely spaced to constrain biozonal boundaries with acceptable accuracy. Instead, as became apparent during BGS surveys in Sussex and Hampshire, it seems that both Brydone and Gaster used topographic features to interpolate their biozonal boundaries between fossil localities. Chalk formation boundaries mapped by BGS surveyors, using the methods described in this paper, are commonly coincident with, or close to, the linework on the maps by Brydone and Gaster, allowing for the relative accuracy of the contemporary base maps.

Although trace fossils are very common in the Chalk, identifiable forms are rarely apparent in chalk fragments in the soil. Many flint nodules, however, preserve trace fossils and some occurrences can serve as useful marker horizons. For example, the Lewes Nodular Chalk can be divided into an upper and a lower portion at the Lewes Marl. This bed coincides with the Lewes Tubular Flint, an extensive system of black burrow-form flints (Mortimore, 1986; Mortimore, 2011a, b). Cylindrical fragments of this distinctive flint development can commonly be found in the soil on the Lewes Chalk outcrop in the South Downs. In other parts of the 'Upper Chalk', the trace fossil Zoophycos can commonly be recognised in flint nodules (tending to form characteristic 'sandwich flints', for example). It has known levels of abundance, for example within the lower part of the Newhaven Chalk in the South Downs (Bristow et al., 1997; Mortimore et al., 2001; Aldiss, 2002). The occurrence of 'Zoophycos flints' is rarely diagnostic by itself, but can be useful supporting evidence of lithostratigraphic level.

\subsubsection{Field procedures}


Once the local position of a chalk formation boundary has been proved by observation of the lithology in an exposure or in field brash, the associated landforms are traced laterally, perhaps through pasture or woodland, until the association can be tested again by observation of brash or at another exposure. It is commonly possible to trace a Chalk formation boundary intermittently along between a third and a half of its outcrop length using this kind of landform interpretation, corroborated where possible by direct observation. The location of the breaks of slope can be quickly and accurately determined with adequate precision in the field by pacing, or by using hand-held GPS. This amount of information typically is sufficient to enable the outcrop patterns to be completed by extrapolating them through areas where the topographic features are obscured.

Determination of the topographical expression of formation boundaries is complemented by observation of the landforms that characterise each formation outcrop as a whole, as described below. In addition, observation of characteristic rock types or fossils can provide useful clues about the stratigraphic position of a locality within a formation. Examples of markers that can be observed in the field are described by Mortimore (2011a). Some distinctive beds that occur locally, such as the Stockbridge Rock Member, which occurs in the Seaford Chalk in Hampshire (Booth, 2002), or very widely, such as Whitaker's 3-inch Flint (Mortimore et al., 2001), can be mapped in places.

For geological mapping purposes, the correspondence between topography and bedrock lithology breaks down where the superficial cover is particularly thick, where the ground has been significantly modified anthropogenically, or where the topography is dominated by planar marine erosion surfaces or the like. However, such areas commonly have their own topographic character and are generally recognisable by a competent field geologist. Where landform interpretation cannot be reliably applied to the mapping of the Chalk formations, it may be possible to use other criteria. For example, the Chalk exposed at the coast in West Sussex has been eroded to form a Late Quaternary marine erosion surface. Work by Martin (1932, 1938) demonstrated the distribution of the major biozonal divisions on this section of the coast. When the geological maps of West Sussex were revised in the 1990s, the biozonal mapping was reinterpreted in terms of lithostratigraphy (Aldiss, 2002). Similarly, in Norfolk, where much of the Chalk is covered by Quaternary glacial deposits, and landforms are correspondingly rarely indicative of Chalk stratigraphy, biozonal determinations by Peake and Hancock $(1961 ; 1970)$ were used by BGS to infer the traditional three-fold subdivision of the Chalk in the Fakenham (British Geological Survey, 1999) and Swaffham (British Geological Survey, 1998) districts.

In practice, landform interpretation for geological mapping depends on the judgement of individual surveyors. While the best test of the interpretation of a landform is its correspondence with direct observations of the bedrock, other important tests of consistency are applied during geological survey. Although there are regional variations in chalk formation thickness, if a mapped formation boundary is seen to converge with an adjacent one over a short distance, then mistaken interpretation of landforms may be suspected. Furthermore, those features produced by bedrock will persist over a significant distance and will conform with other indications of bedrock structure, while those due to superficial deposits, anthropogenic or other localised phenomena will not. In any case, the relationship between topographic expression and bedrock lithology should be corroborated wherever possible by direct observation of exposures, or of brash, borehole data or palaeontological information.

Subjective variations in interpretation by different geologists can also be reduced by good project management. BGS surveyors working on the Chalk are provided with a written 
specification of the criteria used to determine formation boundaries, and are trained in the field. Field meetings are held where needed to resolve issues of disagreement or uncertainty that might arise during the survey, and to inspect work in progress. Most critically, geological surveys generally proceed by the successive completion of 'tiles' corresponding to each Ordnance Survey 1:10 000 scale map sheet, each representing an area of $5 \mathrm{~km}$ by $5 \mathrm{~km}$. Adjacent tiles are commonly surveyed by different geologists, working at different times. 'Edge-matching', the process whereby the seamless continuity of geological boundaries from one tile to another is ensured, is a potent test of the consistency of geological interpretation between individuals. Nevertheless, it must be accepted that close control of the geological interpretation of Chalk landforms by direct observation is not everywhere possible, that the precision of the survey will vary and that misinterpretations do occur.

\subsection{Landforms associated with unexposed Chalk formations in southern England}

The Chalk everywhere forms an escarpment, sometimes referred to as the 'main' or 'primary' escarpment (Figures 3a and 3b). Its profile varies from place to place. For example, although the section from near Wantage in the north of the Berkshire Downs (Figure 3b) is in most respects representative of the region, it displays an unusually broad outcrop width for the West Melbury Chalk. The crest of the escarpment is formed by the Lewes Nodular Chalk Formation or by the Seaford Chalk, while most of the dip slope, which can be as much $15 \mathrm{~km}$ long, is underlain by the Seaford Chalk. Further south, as in Sussex and Dorset, the dip slope behind the main escarpment is interrupted by a 'secondary escarpment', formed by the Newhaven Chalk and Culver Chalk formations (Figure 3a). A relationship between this landform and the Chalk stratigraphy was described by Sparks (1949), who noted that the Chalk of the quadratus Zone (which broadly corresponds to the Culver Chalk; Table 1) contains fewer marl seams than the underlying chalk of the Offaster and Marsupites zones, although Small and Fisher (1970) thought the greater flint content of the chalk at the top of the secondary escarpment to be more significant. In places a third escarpment is formed within the Culver Chalk, and the Portsdown Chalk Formation can form a fourth (Bristow et al., 1997).

The following descriptions are of typical occurrences of each formation as they are seen in unexposed ground without significant cover of superficial deposits, for example on spurs between valleys in the face of the chalk escarpments. Similar landforms can commonly be found in the sides of dip-slope valleys but tend to be more subdued. There are some local or regional variations in how the sometimes subtle differences in composition between the chalk formations are expressed in contrasting landforms, and the requirement for continual local validation of the landform interpretation is emphasized.

While much of the lateral variation in the detail of landforms associated with each formation seems to be due to gradual variations in lithofacies, some other variation occurs with structural attitude. In most outcrops, the Chalk dips gently, at less than about $2^{\circ}$. Although essentially the same landforms can generally be recognised where the dip is steeper, as around periclinal folds in Berkshire (Figures 1 and 5), or in the monoclines of the Isle of Wight and Surrey, the width of each formation's outcrop becomes considerably less and the topographic features become more subtle, especially in near-vertical strata.

Yet other variation can be attributed to the local history of erosion and weathering. In Cambridge, Suffolk and Norfolk, the primary Chalk escarpment is extremely subdued, with overall relief of less than $40 \mathrm{~m}$, compared with more than $80 \mathrm{~m}$, typically, in the Chilterns and more than $120 \mathrm{~m}$ in the South Downs. This could be partly due to lateral changes in chalk lithofacies (for example, in most of Suffolk the base of the Lewes Chalk is formed by the Brandon Flint Member (Mortimore and Wood, 1986) rather than by the Chalk Rock, as found 
in the Chilterns), but it seems likely that there is also an effect of extensive erosion associated with the Anglian ice sheet and locally intense periglacial weathering during the Devensian. Although the base of the Holywell Nodular and Lewes Nodular chalk formations can be mapped in that area by tracing their associated landforms, other formation boundaries, such as that of the New Pit Chalk, cannot.

The composition of each formation is summarised in Tables 2 and 3, and described in more detail by Bristow et al. (1997) and by Hopson (2005). Details are also given in the BGS Lexicon of Named Rock Units, which is accessible on-line at http://www.bgs.ac.uk/Lexicon/.

\subsubsection{West Melbury Marly Chalk Formation}

The West Melbury Marly Chalk Formation everywhere crops out at the foot of the main escarpment formed by the Chalk (Figures 3a and 3b). It generally underlies gently sloping ground, but in places in Wiltshire it forms a subsidiary escarpment up to $30 \mathrm{~m}$ high, above the Upper Greensand, with a dip slope locally in excess of $1.5 \mathrm{~km}$ long. The limestone beds tend to form positive features; mostly these are minor but in Berkshire they include outlying hills (Figure 3b), such as the Sinodun Hills (about $5 \mathrm{~km}$ east of Didcot). The base of the Chalk is typically marked by a weak negative topographic feature above uniformly sloping ground of the Gault outcrop, or at the end of the Upper Greensand dip slope, although in parts of Berkshire this is modified by a subsidiary positive feature at the top of the Upper Greensand (Figures 3b and 3c). The basal Chalk boundary is rarely exposed, but can be proved by augering or trenching. It can be a spring line, particularly where the Upper Greensand is absent and the Chalk rests directly on the Gault, but springs more commonly occur at limestone beds within the West Melbury Chalk. In general, the interpretation of springs as stratigraphic markers within the Chalk should be made with caution, if at all.

\subsubsection{Zig Zag Chalk Formation}

The Zig Zag Chalk occurs low in the main Chalk escarpment, typically forming steeper ground than the West Melbury Chalk (Figures 3a and 3b). Although the marl-limestone rhythms of the West Melbury Chalk (Table 3) continue into the lower part of the Zig Zag Chalk, they rarely have any topographic expression. Where the ground is steep, as in parts of Wiltshire, the outcrop of the Zig Zag Chalk is characterised by alternating buttresses and down-slope gullies creating a corrugated surface with an amplitude of as much as $3 \mathrm{~m}$ (Booth, 2011, plates 8 and 11). This is thought to be related to the development of large-scale orthogonal joint sets in thickly-bedded chalk.

As found by Bristow et al. (1997), the base of the Zig Zag Chalk nearly everywhere occurs at a negative break of slope (Figures 3 and 5). In some parts of the South Downs and of the North Downs, for example, the negative feature approximately corresponds to the local limit of farmland, with the steeper ground of the Zig Zag Chalk outcrop being wooded. This boundary tends to be mapped with the least supporting stratigraphic information, but where it can be constrained, for example by palaeontological analysis of associated brash, the bounding topographic feature corresponds to the horizon of the Totternhoe Stone or of the Cast Bed (Hopson, 2005; Table 3). In places, for example in West Sussex, the topmost bed of the West Melbury Chalk forms a minor positive topographic feature, and can be shown by the fossil assemblage in brash to be the Tenuis Limestone, which there underlies the Cast Bed (Aldiss, 2002; Hopson, 2005). In Wiltshire, the Cast Bed occurs at the top of an escarpment up to $40 \mathrm{~m}$ high. Contrary to some accounts, this formation boundary does not, as a rule, form a spring line. 


\subsubsection{Holywell Nodular Chalk Formation}

The Holywell Nodular Chalk typically underlies relatively gently sloping ground in the middle part of the main Chalk escarpment, usually above a positive topographic feature marking the Melbourn Rock, which is close to the base of the formation (Hopson, 2005; Table 3). The base of the Holywell Chalk occurs just below this positive feature, a position which commonly coincides with a faint negative break of slope marking the basal Plenus Marls, a relative paucity of brash, and locally increased clay content in the soil (Figures 3 and 5). In rare instances, fragments of finely laminated marl can be found in the soil. In parts of Berkshire, a second positive feature occurs at the top of the Zig Zag Chalk (Figure 3c). In many areas, such as in the South Downs, the Holywell Chalk outcrop is quite narrow (Figure 3a) but being relatively resistant, this formation can form its own subsidiary escarpment, locally capping spurs and outliers, as in Berkshire (Aldiss et al., 2009), the Chilterns and East Anglia (where the Holywell Chalk dip slope is the site of several major airfields).

\subsubsection{New Pit Chalk Formation}

The New Pit Chalk underlies uniformly steep slopes in the upper part of the main Chalk escarpment, typically forming the steepest ground. In most areas, the base of the formation is consistently marked by a distinct negative break of slope above the Holywell Chalk outcrop (Figures 3, 4 and 5). However, in describing the Chalk of Sussex and Dorset, Bristow et al. (1997) stated that this boundary tends not to have a topographic expression everywhere. This landform also fails in the Thetford district of Suffolk and there, in the general absence of brash (due to a very thick mantle of periglacially weathered bedrock), the base of the New Pit Chalk cannot be mapped.

\subsubsection{Lewes Nodular Chalk Formation}

The marked lithological change at the base of the Lewes Chalk (Tables 2 and 3) typically occurs at a positive break of slope, or locally just below it, marking the boundary between the steep, uniform slope of the New Pit Chalk outcrop and a broad convex slope above it, which in most areas forms the top of the main Chalk escarpment (Figures 3 and 5). The textural changes marking the base of the Lewes Chalk can be gradational over a few metres, but there is a consistent association between this change and the landform. The Chalk Rock, where it occurs, commonly is clearly marked in the soil by fragments of chalkstone with glauconitic or phosphatic mineralisation, or with glauconite grains. In much of the Chilterns, it marks the base of the Lewes Chalk. In Suffolk, however, the Chalk Rock is much reduced and in the Thetford district there is only a very subdued Chalk escarpment in which the positive break of slope associated with the base of the Lewes Chalk coincides with the Brandon Flint Member (Mortimore and Wood, 1986; Mortimore et al., 2001).

\subsubsection{Seaford Chalk Formation}

The Seaford Chalk typically forms extensive dip slopes extending from the crest of the main Chalk escarpment down to the secondary Newhaven Chalk escarpment (Figure 3a), or to where the chalk dip slope is covered by Palaeogene and Quaternary deposits, as in Berkshire and the Chilterns. In East Kent, however, a secondary escarpment has formed within the Seaford Chalk.

The base of the Seaford Chalk is taken at the upward limit of nodularity and grittiness of the Lewes Chalk, as seen in brash as an upwards change from rubbly, hard nodular chalks to smooth, white soft chalks (Hopson, 2005). This change is gradational and can be difficult to locate in the field and in boreholes, and so the base of the Seaford Chalk can be difficult to survey. Nevertheless it typically forms a very slight (locally exceedingly slight) negative feature associated with the change in brash, where the steeply convex slope marking the 
Lewes Chalk gives way to a much flatter convex slope, rising to a crest associated with the Seaford Chalk outcrop (Figures 3 and 5). Even though the boundary can rarely be precisely sited with confidence in any individual traverse, systematic survey team work demonstrates that it can be recognised consistently. Cultivated fields on the Seaford Chalk typically have piles of nodular flints at their margins, arising from agricultural stone clearance. The occurrence of such piles can help distinguish the outcrop of the Seaford Chalk, particularly from that of the Newhaven Chalk.

\subsubsection{Newhaven Chalk Formation}

The outcrop of the Newhaven Chalk is normally associated with steeper ground than the Seaford Chalk, so that it tends to form the face of the 'secondary escarpment'. This is most clearly developed in the South Downs (Figure 3a) but an analogous landform occurs through the Wessex Downs and in a much subdued form in parts of the Berkshire Downs.

The base of the Newhaven Chalk is defined by the incoming of common marl seams above the flinty marl-free chalks of the Seaford Chalk (Bristow et al., 1997; Hopson, 2005), although it is commonly recognised by the appearance of a particular assemblage of bioclastic debris, described in Section 4.2.2. These changes in the lithological assemblage commonly coincide with a negative break of slope (although this is exceedingly slight in some areas), assumed to mark one or more persistent marl seams. This break of slope is not always present, especially if the boundary occurs close to the base of the Palaeogene, as in parts of Berkshire (Aldiss et al., 2009). In some places, it can be accurately located (or observed at all) only when lying prone on the ground, looking uphill along the crests of spurs in the face of the escarpment (Farrant et al., 2001). In some areas this negative break of slope occurs a short way above a rounded positive break of slope, which seems to be caused by an indurated horizon at the top of the Seaford Chalk. In Wiltshire and parts of Dorset, the negative break of slope occurs about $10 \mathrm{~m}$ above the base of the Newhaven Chalk, within the M. testudinarius Zone.

Other persistent negative breaks of slope occur within the outcrop of the Newhaven Chalk, near the base. Together these can give the impression of a concave slope, but they are separated by facets of uniformly sloping ground. The relative prominence of these features in different areas seems to depend on the overall steepness of the ground and probably also on the local relationship of the structural dip to the slope.

In East Kent, the base of the Margate Chalk, which locally represents the Newhaven Chalk, is found in some places to coincide with a weak to very weak negative feature, bounded above and below by broad gentle convex slopes (Aldiss et al., 2004).

\subsubsection{Culver Chalk Formation}

The Culver Chalk caps the secondary Chalk escarpment and underlies much of the dip slope behind, the base of which is commonly covered by Palaeogene formations (Figure 3a). In the field, the base of the Culver Chalk is generally taken just below a strong persistent positive topographic feature coinciding with the appearance of abundant large flint nodules, the Castle Hill Flints of Mortimore (1986). In places, a negative feature occurs a few metres below this level, and where present this has been taken as the base of the Culver Chalk.

In parts of Dorset, Hampshire and Sussex, the Culver Chalk can be divided into a lower Tarrant Chalk Member and an upper Spetisbury Chalk Member (Table 1). The base of the Spetisbury Chalk is typically marked by a positive feature at the top of a subsidiary escarpment within the Culver Chalk outcrop, which is visible on Landsat imagery (Bristow et al., 1997). 


\subsubsection{Portsdown Chalk Formation}

In Dorset and Hampshire, the base of the Portsdown Chalk is taken at a negative feature at the base of a fourth escarpment, formed by the youngest part of the Chalk Group (Bristow et al., 1997).

\section{Summary and conclusions}

Geological field survey and supporting work over almost two decades has demonstrated that nine formations of the Chalk Group can be consistently and systematically mapped throughout most of their outcrop in southern and eastern England. Delineation of the boundaries between these formations in unexposed ground, much of which is vegetated or built-over, depends largely on the recognition of the characteristic topographic expression of each formation. The type and appearance of topographic features associated with each of the formations, and in particular with the boundaries between them, is determined by observation of exposures or of brash, or by interpretation of borehole data or palaeontological information. During field survey, the inferred correlation between lithostratigraphy and topographic expression should be corroborated wherever possible.

Local and regional variations in the topographic expression of the formations are attributed to various factors, including regional changes in Chalk lithofacies and lithostratigraphy, structural attitude of the Chalk, local history of erosion and weathering, and cover by superficial deposits.

Revised geological maps of the Chalk that show the distribution of the nine Chalk formations provide a better understanding of the local geological structure than the previous versions. They are more useful in applied geological studies, especially for geotechnical and hydrogeological work. They also provide a sound basis for the construction of 3D geological models, the subject of current and planned future work by the British Geological Survey (Ford et al., 2010).

It is thought that knowledge of the techniques and criteria used to produce these new geological maps, as described here, will promote understanding of their meaning and potential use, and also of their limitations.

It is probable that the concepts used by the BGS to map the formations in the English Chalk Group can be applied elsewhere in the world, to subdivide other geological successions in which compositional variation is subtle but significant.

\section{Acknowledgements}

This paper is based on a presentation given by DTA to a joint meeting of the Engineering Geology Group and the Thames Valley Regional Group of the Geological Society of London on the Engineering Geology of the Chalk, convened at Reading University on 20 April 2004. It is based partly on work carried out by the BGS Regional Mapping Programme and partly on similar work commissioned by the Environment Agency at various times. We thank our numerous colleagues and other collaborators with whom we have worked on the Chalk, especially Luke Bateson, Roger Bristow, Katy Lee (née Booth), Rory Mortimore, Andy Newell, Jo Thompson (née Brayson), Ian Wilkinson, Chris J Wood and Mark Woods. We also thank two anonymous reviewers for their careful attention and thoughtful comments, which have helped us make some significant improvements. The paper is published with the permission of the Executive Director, BGS. 


\section{References}

Aldiss, D.T., 2002. Geology of the Chichester and Bognor district. Sheet Description of the British Geological Survey 1:50 000 Sheet 317 and Sheet 332 (England and Wales).

Aldiss, D.T., Bloomfield, J.R., Buckley, D.K., Doran, S.K., Evans, D.J., Hopson, P.M., Royse, K.R., Woods, M.A., 2004. A geological model of the Chalk of East Kent. British Geological Survey Commissioned Report, CR/04/092.

Aldiss, D.T., Newell, A.J., Marks, R.J., Hopson, P.M., Farrant, A.R., Royse, K.R., Aspden, J.A., Evans, D.J., Smith, N.J.P., Woods, M.A., Wilkinson, I.P., 2009. Geology of the Newbury district and part of the Abingdon district. Sheet Description of the British Geological Survey 1:50 000 Sheet 267 and part of Sheet 253 (England and Wales), 146 pp.

Allum, J.A.E., 1966. Photogeology and regional mapping. Pergamon Press, Oxford.

Barnes, J.W., 1981. Basic geological mapping. The Open University Press, Milton Keynes.

Barker, R.D., Lloyd, J.W., Peach, D.W., 1984. The use of resistivity and gamma logging in lithostratigraphical studies of the Chalk in Lincolnshire and South Humberside. Quarterly Journal of Engineering Geology \& Hydrogeology 17, 71-80.

Belt, K., Paxton, S.T., 2005. GIS as an aid to visualizing and mapping geology and rock properties in regions of subtle topography. Geological Society of America Bulletin 117, 149160.

Berridge, N.G., Pattison, J., Samuel, M.D.A., Brandon, A., Howard, A.S., Pharaoh, T.C., Riley, N.J., 1999. Geology of the Grantham district. Memoir of the British Geological Survey Sheet 127 (England and Wales).

Booth, K.A., 2002. Geology of the Winchester district - a brief explanation of the geological map. Sheet Explanation of the British Geological Survey 1:50 000 Sheet 299 Winchester (England and Wales).

Booth, K.A., 2011. Geology of the Devizes district. Sheet Description of the British Geological Survey Sheet 282 (England and Wales).

Brandon, A., Sumbler, M.G., Ivimey-Cook, H.C., 1990. A revised lithostratigraphy for the Lower and Middle Lias (Lower Jurassic) east of Nottingham, England. Proceedings of the Yorkshire Geological Society 48, 121-141.

Bristow, C.R., Barton, C.M., Freshney, E.C., Wood, C.J., Evans, D.J., Cox, B.M., IvimeyCook, H.C., Taylor, R.T., 1995. Geology of the country around Shaftesbury. Memoir of the British Geological Survey.

Bristow, C.R., Mortimore, R.N., Wood, C.J., 1997. Lithostratigraphy for mapping the Chalk of southern England. Proceedings of the Geologists' Association 108, 293-315.

British Geological Survey, 1998. Swaffham. England and Wales Sheet 160. British Geological Survey, Keyworth, Nottingham.

British Geological Survey, 1999. Fakenham. England and Wales Sheet 146. British Geological Survey, Keyworth, Nottingham.

Bromley, R.G., Gale, A.S., 1982. The lithostratigraphy of the English Chalk Rock. Cretaceous Research 3, 273-306.

Brydone, R.M., 1912. The stratigraphy of the Chalk of Hants. Dulau and Co. Ltd, London.

Brydone, R.M., 1942. Some zonal notes on the Chalk of Hants. Jarrold and Sons, London.

Catt, J.A., Hodgson, J.M., 1976. Soils and geomorphology of the chalk in South East England. Earth Surf. Processes 1, 181-193.

Chadwick, R.A., 1993. Aspects of basin inversion in Southern Britain. Journal of the Geological Society, London 150, 893-911.

Clark, M.J., 1965. The form of chalk slopes. University of Southampton Department of Geography, Research Series 2, 3-4.

Farrant, A.R., Hopson, P.M., Booth, K.A., Aldiss, D.T., 2001. Geology of the Bourne River catchment. British Geological Survey Internal Report, IR/01/157. 
Farrant, A.R., Hopson, P.M., Woods, M.A., Booth, K.A., Evans, D.J., 2012. Comment on "Structural geology of the Upper Cretaceous Chalk Central Mass, Isle of Wight, UK by Rory Mortimore”. Proceedings of the Geologists' Association, vol. 122 (2), pp. 298-331. Proceedings of the Geologists' Association.

Ford, J.R., Mathers, S.J., Royse, K.R., Aldiss, D.T., Morgan, D.J.R., 2010. Geological 3D modelling: scientific discovery and enhanced understanding of the subsurface, with examples from the UK. Zeitschrift der Deutschen Gesellschaft für Geowissenschaften 161, 205-218.

Foster, S.S.D., 1993. The Chalk aquifer - its vulnerability to pollution, In: Downing, R.A., Price, M., Jones, G.P. (Eds.), The Hydrogeology of the Chalk of North-West Europe. Clarendon, Oxford, pp. 93-112.

Gale, A.S., 1996. Turonian correlation and sequence stratigraphy of the Chalk in southern England, In: Hesselbro, S.P., Parkinson, D.N. (Eds.), Sequence Stratigraphy in British Geology. Geological Society of London Special Publication 103, pp. 177-195.

Gale, A.S., Hardenbol, J., Hathway, B., Kennedy, W.J., Young, J.R., Phansalkar, V., 2002. Global correlation of Cenomanian (Upper Cretaceous) sequences: Evidence for Milankovitch control on sea level. Geology 30, 291-294.

Gale, A.S., Young, J.R., Shackleton, N.J., Crowhurst, S.J., Wray, D.S., 1999. Orbital tuning of Cenomanian marly chalk successions: towards a Milankovitch time-scale for the Late Cretaceous. Philosophical Transactions Of The Royal Society Of London Series AMathematical Physical And Engineering Sciences 357, 1815-1829.

Gallois, R.W., 1965. British Regional Geology: The Wealden District, Fourth ed. HMSO for British Geological Survey, London.

Gaster, C.T.A., 1937. The stratigraphy of the Chalk of Sussex. Part I. West central area Arun Gap to the valley of the Adur, with zonal map. Proceedings of the Geologists'

Association 48, 356-373.

Gaster, C.T.A., 1939. The stratigraphy of the Chalk of Sussex. Part II. Eastern area - Seaford to Cuckmere Valley and Eastbourne, with zonal map. Proceedings of the Geologists' Association 50, 510-526.

Gaster, C.T.A., 1944. The stratigraphy of the Chalk of Sussex. Part III. Western area - Arun Gap to the Hampshire border, with zonal map. Proceedings of the Geologists’ Association 55, 173-188.

Gaster, C.T.A., 1951. The stratigraphy of the chalk of Sussex: Part IV, East central area between the valley of the Adur and Seaford, with zonal map. Proceedings of the Geologists' Association 62, 31-64.

Goudie, A.J., 1990. The landforms of England and Wales. Basil Blackwell, Oxford.

Hancock, J.M., 1975. The petrology of the Chalk. Proceedings of the Geologists' Association 86, 499-535.

Headworth, H.G., Puri, S., Rampling, B.H., 1980. Contamination of a Chalk aquifer by mine drainage at Tilmanstone, East Kent, U.K. Quarterly Journal of Engineering Geology 13, 105117.

Hill, W., Jukes-Browne, A.J., 1886. The Melbourn Rock and the zone of Belemnitella plena from Cambridge to the Chiltern Hills. Quarterly Journal of the Geological Society, London 42, 216-231.

Hopson, P.M., 2005. A stratigraphical framework for the Upper Cretaceous Chalk of England and Scotland with statements on the Chalk of Northern Ireland and the UK Offshore Sector. British Geological Survey Research Report, RR/05/01 (Nottingham).

Hopson, P.M., Aldiss, D.T., Smith, A., 1996. The geology of the country around Hitchin. Memoir of the British Geological Survey Sheet 221 (England and Wales). 
Hopson, P.M., Farrant, A.R., Newell, A.J., Marks, R.J., Booth, K.A., Bateson, L.B., Woods, M.A., Wilkinson, I.P., Brayson, J., Evans, D.J., 2007. Geology of the Salisbury district. Sheet Explanation of the British Geological Survey Sheet 298 Salisbury (England and Wales).

Jukes-Browne, A.J., 1880. On the subdivisions of the Chalk. Geological Magazine 17, 248257.

Jukes-Browne, A.J., Hill, W., 1903. The Cretaceous rocks of Britain. Volume II. The Lower and Middle Chalk of England Memoir of the Geological Survey of the United Kingdom.

Jukes-Browne, A.J., Hill, W., 1904. The Cretaceous Rocks of Britian. Volume III. The Upper Chalk of England. Memoir of the Geological Survey of the United Kingdom.

Kerney, M.P., Brown, E.H., Chandler, T.J., 1964. The late-glacial and post-glacial history of the Chalk escarpment near Brook, Kent. Philosophical Transactions of the Royal Society of London, Series B: Biological Sciences 248, 135-204.

Lott, G.K., Knox, R.W.O., 1994. Post-Triassic of the southern North Sea. British Geological Survey, Nottingham.

Martin, E.C., 1932. Chalk zones on the foreshore between Worthing and Felpham, Sussex. Proceedings of the Geologists' Association 43, 201-211.

Martin, E.C., 1938. The Littlehampton and Portsdown chalk inliers and their relation to the raised beaches of West Sussex. Proceedings of the Geologists’ Association 49, 198-212.

Mortimore, R.N., 1986. Stratigraphy of the Upper Cretaceous White Chalk of Sussex. Proceedings of the Geologists’ Association 97, 97-139.

Mortimore, R.N., 1993. Chalk, water and engineering geology, In: Downing, R.A., Price, M., Jones, G.P. (Eds.), The hydrogeology of the Chalk of north-west Europe. Oxford Science Publications. Clarendon Press, Oxford, pp. 67-92.

Mortimore, R.N., 2011a. A chalk revolution: what have we done to the Chalk of England? Proceedings of the Geologists' Association 122, 232-297.

Mortimore, R.N., 2011b. Structural geology of the Upper Cretaceous Chalk Central Mass, Isle of Wight, U.K. Proceedings of the Geologists' Association 122, 298-331.

Mortimore, R.N., Newman, T.G., Royse, K., Scholes, H., Lawrence, U., 2011. Chalk: its stratigraphy, structure and engineering geology in east London and the Thames Gateway. Quarterly Journal of Engineering Geology and Hydrogeology 44, 419-444.

Mortimore, R.N., Pomerol, B., Foord, R.J., 1990. Engineering stratigraphy and palaeogeography for the Chalk of the Anglo-Paris Basin, In: Burland, J.B., Mortimore, R.N., Roberts, L.D., Jones, D.L., Corbett, B.O. (Eds.), Chalk. Thomas Telford, London, pp. 47-61. Mortimore, R.N., Wood, C.J., 1986. The distribution of flint in the English Chalk, with particular reference to the 'Brandon Flint Series' and the high Turonian flint maximum, In: Sieveking, G., de G, Hart, M.B. (Eds.), The scientific study of flint and chert: proceedings of the Fourth International Flint Symposium held at Brighton Polytechnic 10-15 April 1983. Cambridge University Press, Cambridge, pp. 7-20.

Mortimore, R.N., Wood, C.J., Gallois, R.W., 2001. British Upper Cretaceous Stratigraphy. Joint Nature Conservation Committee, Peterborough.

Moseley, F., 1981. Methods in field geology. W H Freeman \& Co. Ltd, Oxford.

Murray, K.H., 1986. Correlation of electrical resistivity marker bands in the Cenomanian and Turonian Chalk from the London Basin to east Yorkshire. British Geological Survey Report, Vol. 17, No. 8 (Keyworth, Nottingham).

Peake, N.B., Hancock, J.M., 1961. The Upper Cretaceous of Norfolk. Transactions of the Norfolk and Norwich Naturalists' Society, Vol.19.

Peake, N.B., Hancock, J.M., 1970. The Upper Cretaceous of Norfolk [reprinted with corrigenda and addenda], In: Larwood, G.P., Funnell, B.M. (Eds.), The Geology of Norfolk, London \& Ashford. 
Powell, J.H., 1993. Geological Field Surveying - An Introduction to Feature Mapping Course Notes and Manual. BGS Earth Science Training Course.

Small, R.J., Fisher, G.C., 1970. The origin of the secondary escarpment of the South Downs. Transactions of the Institute of British Geographers 49, 97-107.

Smart, J.G.O., Bisson, G., Worssam, B.C., 1966. Geology of the country around Canterbury and Folkestone. Memoir of the Geological Survey of Great Britain Sheets 289, 305 and 306 (England and Wales).

Smith, A.B., Batten, D.J., 2002. Fossils of the Chalk. Palaeontological Association Field

Guides to Fossils, Number 2. Second edition, The Palaeontological Society, London.

Sparks, B.W., 1949. The denudation chronology of the dip-slope of the South Downs. Proceedings of the Geologists’ Association 60, 165-215.

Sumbler, M.G., 1999. The stratigraphy of the Chalk Group in Yorkshire and Lincolnshire. British Geological Survey Technical Report, WA/99/02 (Nottingham).

van Zuidam, R.A., 1985. Aerial photo-interpretation in terrain analysis and geomorphologic mapping. Smits, The Hague.

Warren, C.D., Mortimore, R.N., 2003. Chalk engineering geology - Channel Tunnel Rail Link and North Downs Tunnel. Quarterly Journal of Engineering Geology and Hydrogeology 36, 17-34.

Wood, C.J., Smith, E.G., 1978. Lithostratigraphical classification of the Chalk in North Yorkshire, Humberside and Lincolnshire. Proceedings of the Yorkshire Geological Society 42.

Woods, M.A., 2006. UK Chalk Group stratigraphy (Cenomanian-Santonian) determined from borehole geophysical logs. Quarterly Journal of Engineering Geology and Hydrogeology 39, 83-96.

Woods, M.A., Aldiss, D.T., 2004. The stratigraphy of the Chalk Group of the Berkshire Downs. Proceedings of the Geologists' Association 115, 249-265.

Woods, M.A., Aldiss, D.T., Hopson, P.M., 2002. Invited comments on Peake's 'Plea to subdivide the Chalk'. Proceedings of the Geologists' Association 113, 348-351.

Wray, D.S., 1999. Identification and long-range correlation of bentonites in TuronianConiacian (Upper Cretaceous) chalks of northwest Europe. Geological Magazine 136, 361371.

Young, B., Lake, R.D., 1988. Geology of the country around Brighton and Worthing. Memoir of the British Geological Survey Sheets 318 and 333 (England and Wales). 
Table 1: Summary of evolving stratigraphic nomenclature of the Chalk Group in England

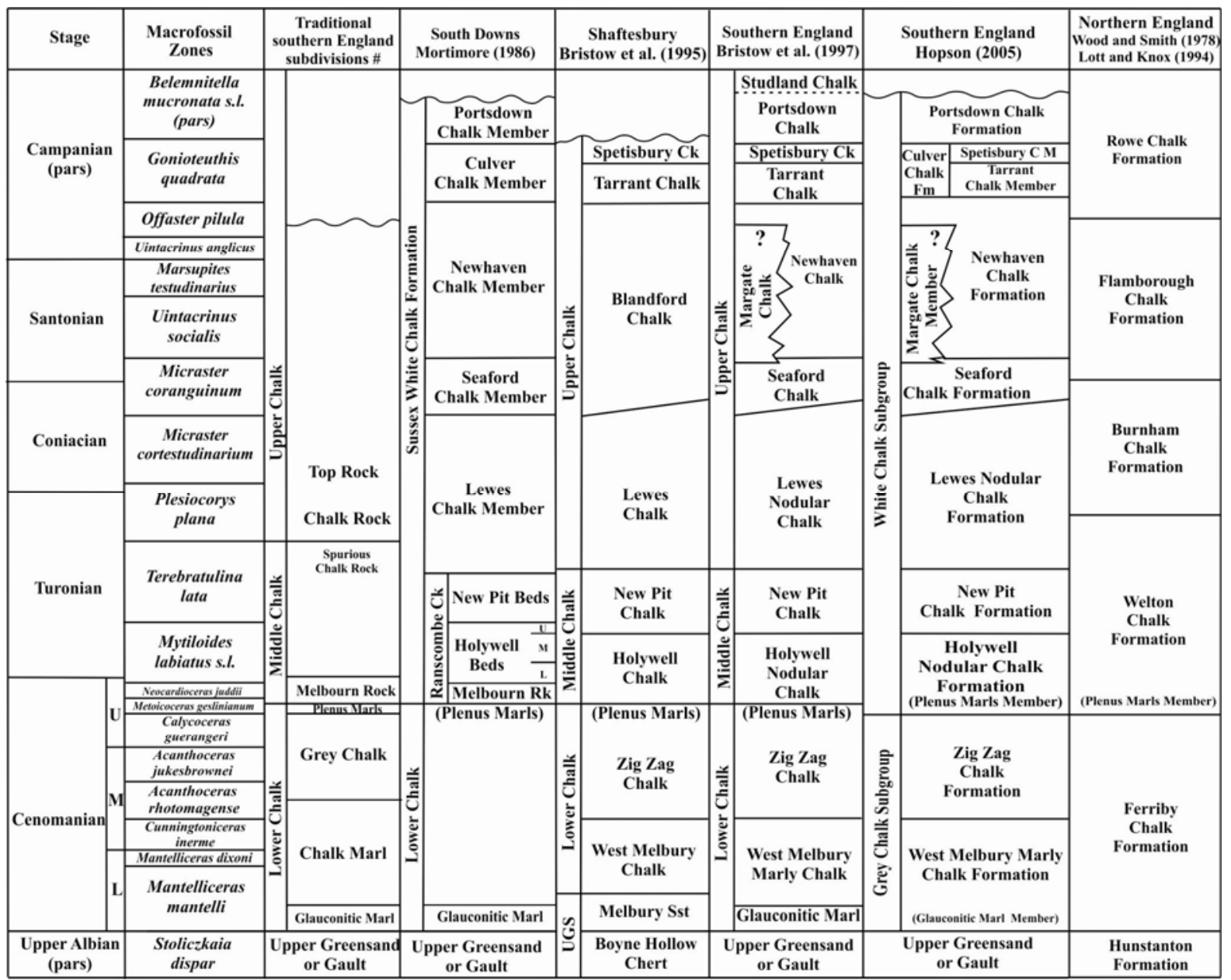

\# After Jukes-Browne and Hill (1903, 1904), for example. Not to scale

L = Lower; $\mathrm{M}$ = Middle; U = Upper; UGS = Upper Greensand 


\section{Table 2}

Summary of lithostratigraphy of the Chalk of southern England

\begin{tabular}{lll}
\hline Formation & Typical composition & Typical thickness \\
\hline Portsdown Chalk & Chalk with marl seams, some flint & About 60 \\
$\begin{array}{l}\text { Culver Chalk } \\
\text { Newhaven Chalk }\end{array}$ & Chalk with flint but few or no marl seams & About 70 \\
$\begin{array}{l}\text { Seaford Chalk } \\
\text { Lewes Nodular }\end{array}$ & Chalk with few marl seams, much flint & 50 to 80 \\
$\begin{array}{l}\text { Chalk } \\
\text { New Pit Chalk }\end{array}$ & Chalk with marl seams, sparse flint & 35 to 50 \\
$\begin{array}{l}\text { Holywell } \\
\text { Nodular Chalk }\end{array}$ & Nodular, gritty chalk, with marl seams & 25 to 35 \\
$\begin{array}{l}\text { Zig Zag Chalk } \\
\begin{array}{l}\text { West Melbury } \\
\text { Marly Chalk }\end{array}\end{array}$ & Chalk, some marly, some hard & 35 to 50 \\
\hline Thicknesses are in metres & 15 to 30 \\
\hline
\end{tabular}




\section{Table 3}

Characteristic rock types and brash associated with Chalk formations in southern England

\begin{tabular}{llll}
\hline Formation & Typical composition & Characteristic brash* & Typical associated topography \\
\hline $\begin{array}{l}\text { Portsdown } \\
\text { Chalk }\end{array}$ & $\begin{array}{l}\text { White flinty chalk with common marl seams and } \\
\text { some flint bands }\end{array}$ & $\begin{array}{l}\text { Associated brash cannot be reliably distinguished } \\
\text { from that of Culver Chalk on lithological } \\
\text { grounds alone }\end{array}$ & $\begin{array}{l}\text { Outcrop includes face and dip slope of a fourth } \\
\text { escarpment. Base at a negative break of slope at } \\
\text { base of that escarpment }\end{array}$
\end{tabular}

Culver Chalk Soft white chalks without significant marl seams, Tends to be more blocky than that from the but with some very strongly developed nodular, horn and semi-tabular flints

Newhaven

Chalk

Soft to medium-hard, blocky smooth white chalks with numerous marl seams and bands of flint nodules (generally smaller than those in the Seaford Chalk). Some beds rich in bioclastic debris occur at intervals

Seaford Chalk Soft blocky smooth white chalk with abundant seams of large nodular and semi-tabular flint, with thin beds of harder nodular chalk near the base

Lewes Nodular Chalk
Hard to very hard, white to creamy or yellowish white nodular chalks and chalkstones, with interbedded soft to hard gritty white chalks and common seams of clay-rich chalk (marl seams). Regular bands of nodular flint, some large, occur more commonly than in the underlying beds

The Chalk Rock (a variable sequence of

mineralised hardgrounds, chalkstone and nodular
Newhaven Chalk, but most cannot be reliably distinguished on lithological grounds alone. Some parts with abundant bioclastic debris, especially bryozoan debris

Angular slabby fragments of smooth white chalk very similar in appearance to that of the Seaford

Chalk but commonly much more voluminous although in smaller fragments; abundant Zoophycos flints near the base

The volume of flint and the frequency of large flint nodules is generally much greater than on the Newhaven Chalk.

Some of the large flint bands are characteristic enough to be locally recognised in brash. Individual fragments of typical Seaford Chalk are smaller and more equant than those of the Lewes Chalk; flints are generally larger and more abundant

Rubbly, hard nodular chalk fragments and large nodular flints.

Rough-textured and rather flaggy in appearance.

It tends to be more voluminous and rather dirtier than that derived from the New Pit Chalk
Outcrop occupies the dip slope behind the secondary escarpment. Base just below a strong positive break of slope at top of that escarpment. Locally, the formation is divided by a third escarpment

Forms steep ground in the face of the secondary escarpment. Base at a negative break of slope at the foot of that escarpment

Forms extensive dip slopes between primary and secondary escarpment. Base at a very slight negative feature in front of, or at, or behind the crest of that escarpment

Forms a convex slope at the top of the primary escarpment, commonly including the crest. Base at a positive break of slope 
chalk) occurs at or near base of formation

New Pit Chalk Smooth-textured, rather blocky, massively

bedded, firm white chalks, with regular thin beds of clay-rich chalk ('marl seams') and sparse smallish flints

Holywell

Medium hard to very hard, nodular, white to creamy white chalk with beds and laminae of clay-rich chalk (marl), including flaser-laminated marls. A thin alternating sequence of clay-rich chalks and clayey limestones (Plenus Marls) overlain by very hard, creamy white limestone (Melbourn Rock) occurs at base of formation. The upper two-thirds is mostly conspicuously fossiliferous: most beds contain gritty shel debris, commonly pink, and some have mytiloid inoceramid bivalves preserved in three

\section{dimensions}

Zig Zag Chalk Soft to medium-hard, pale grey, blocky chalk with some thin resistant limestone beds near the base. Basal bed is either a fine-grained phosphatic calcarenite (Totternhoe Stone), or silty to calcarenitic chalk (the Cast Bed)

West Melbury Numerous rhythmic alternations, each consisting Marly Chalk

of soft off-white to grey clay-rich chalks (marls) passing up into grey clayey chalks and hard grey or brownish grey limestones. Glauconitic, clayrich, locally sandy, chalk at base (Glauconitic

Marl Member)
Fragments tend to be of very uniform, smooth, brittle white chalk of medium hardness, with little fossil debris. These break readily under the plough and so the brash commonly shows numerous clean broken surfaces

Rougher, more grainy and rubbly brash, compared with New Pit Chalk. Brash is

commonly too hard to be easily broken during normal cultivation, and so tend to develop a rather grubby appearance. In the absence of shell debris, the rather grainy texture of typical Holywell Chalk distinguishes it from the smooth chalks of the succeeding New Pit Chalk

\section{Rather sparse angular or blocky fragments of} grey chalk.

Rough, rubbly limestone fragments locally voluminous; commonly fossiliferous.

Glauconitic base found as brash in places, but is more proven by hand auger samples
Forms the steepest ground in the face of the primary escarpment, typically with a uniform gradient. Base at a negative break of slope

Forms relatively gently sloping ground in the mid part of the primary escarpment, which can slope either towards or away from the escarpment. Base occurs at a weak negative break of slope, just below a strong positive break of slope

Forms relatively steep ground low in the primary escarpment. Base at a negative break of slope

Forms relatively gently sloping ground in the lowest part of the primary escarpment. Locally can form a subsidiary escarpment with a dip slope facing towards the primary escarpment. Base occurs at a weak negative break of slope

*The term 'brash' is commonly used for rock fragments in the soil, especially those derived from local bedrock. 
Figures with captions to accompany

Geological mapping of the Upper Cretaceous Chalk Group of southern England: a specialised application of landform interpretation

D T Aldiss*, A R Farrant and P M Hopson

Figures in colour are intended for colour reproduction on the Web and in print

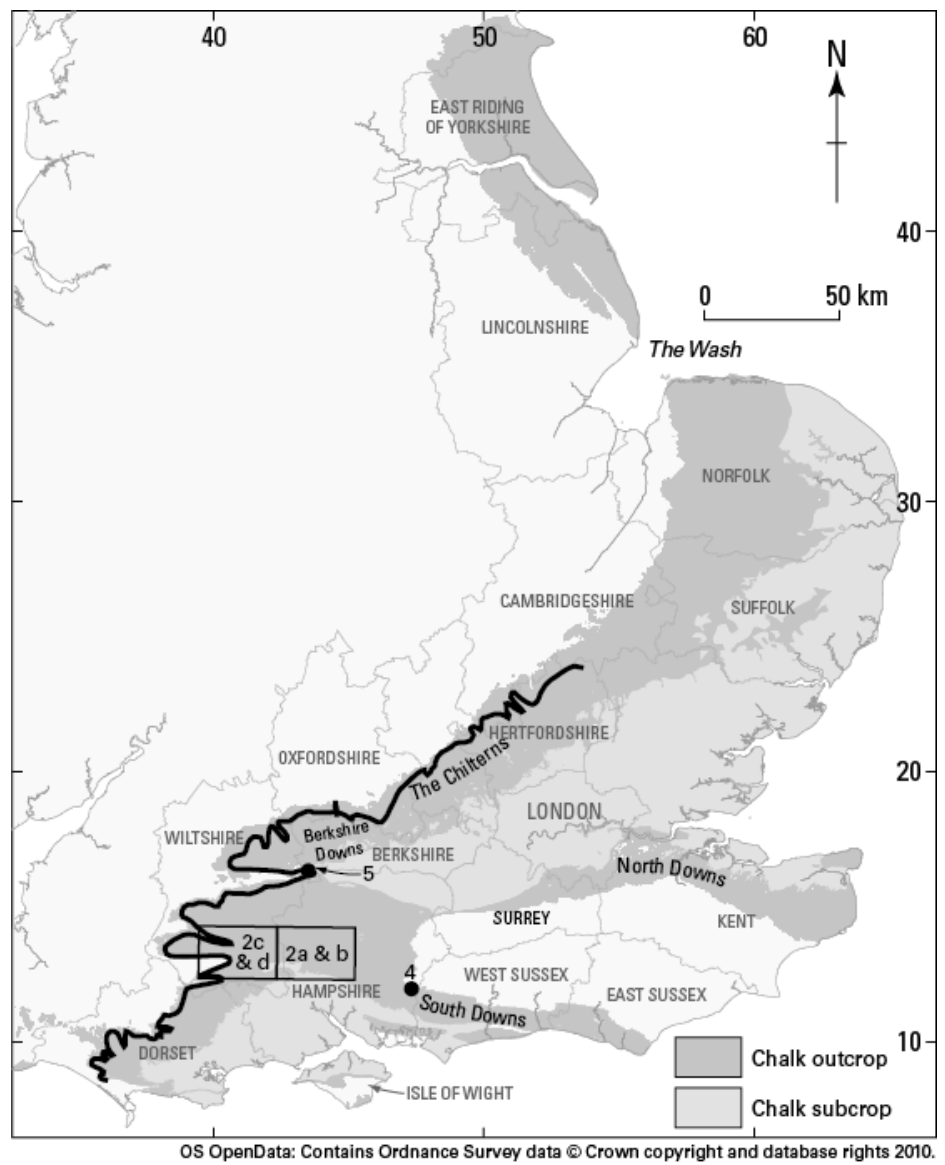

Fig. 1. Distribution of the Chalk Group in England, with the English counties named in the text. The thick black line indicates the outcrop extent of the Chalk Rock (after Bromley and Gale, 1982). Numbers indicate the location of subsequent figures. 

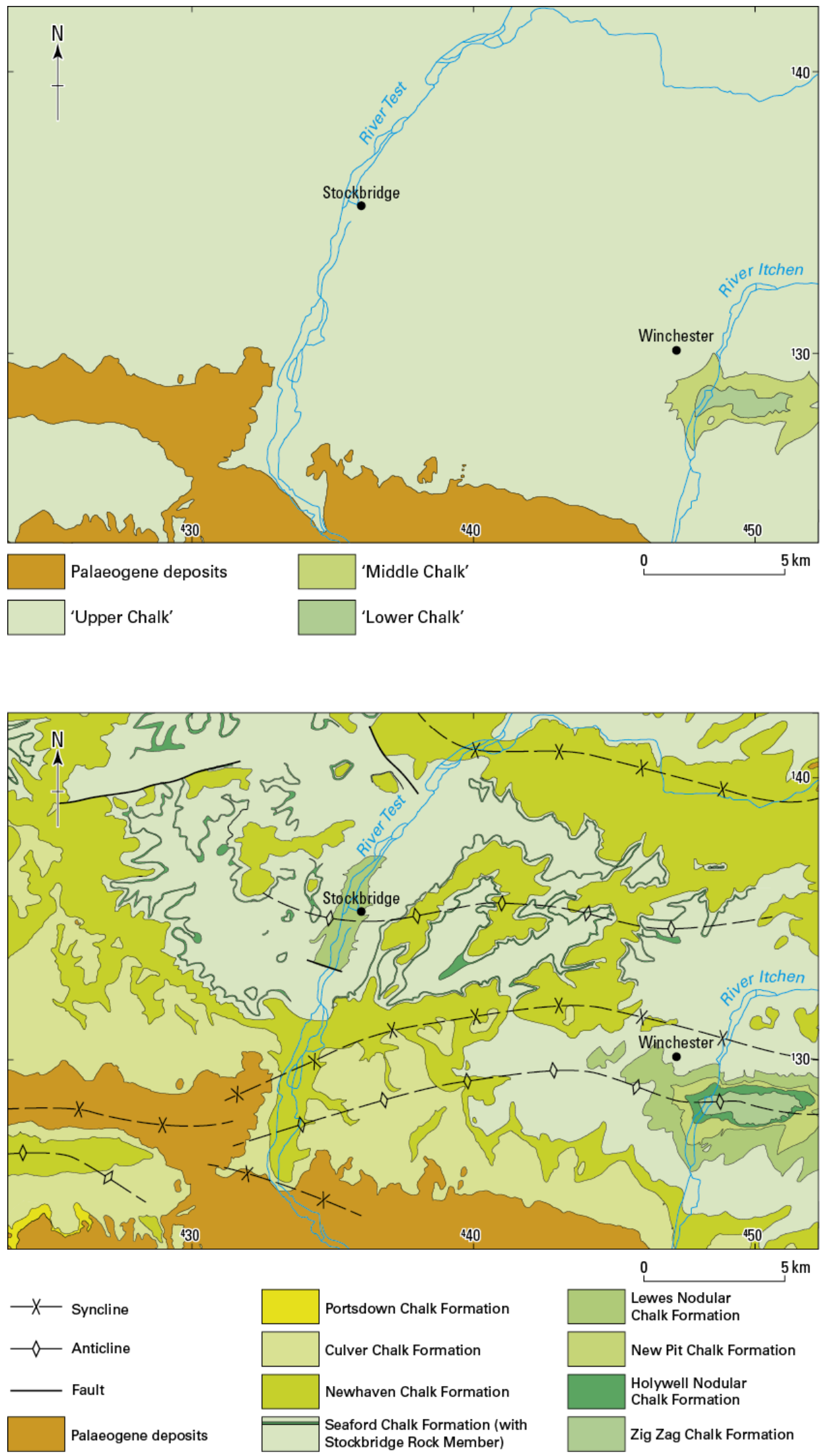

Figs.2a and 2b. Bedrock map of the Winchester district (BGS 1:50 000 scale Geological Sheet 299) using the traditional and modern Chalk lithostratigraphic classifications. In 2b, major fold pairs and faults can be delineated within the Chalk. 

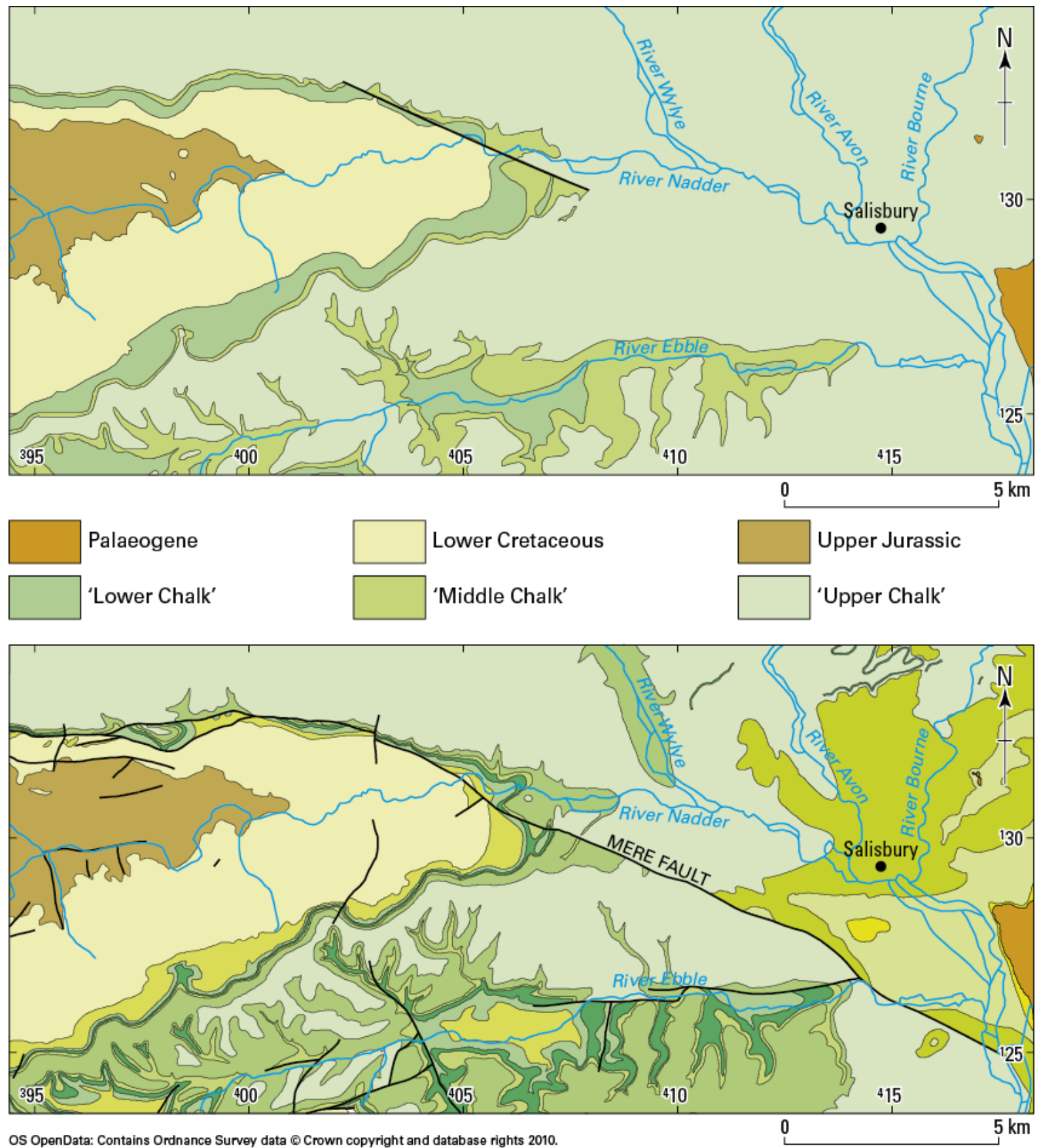

OS OpenData: Contains Ordnance Survey data @ Crown copyright and database rights 2010.
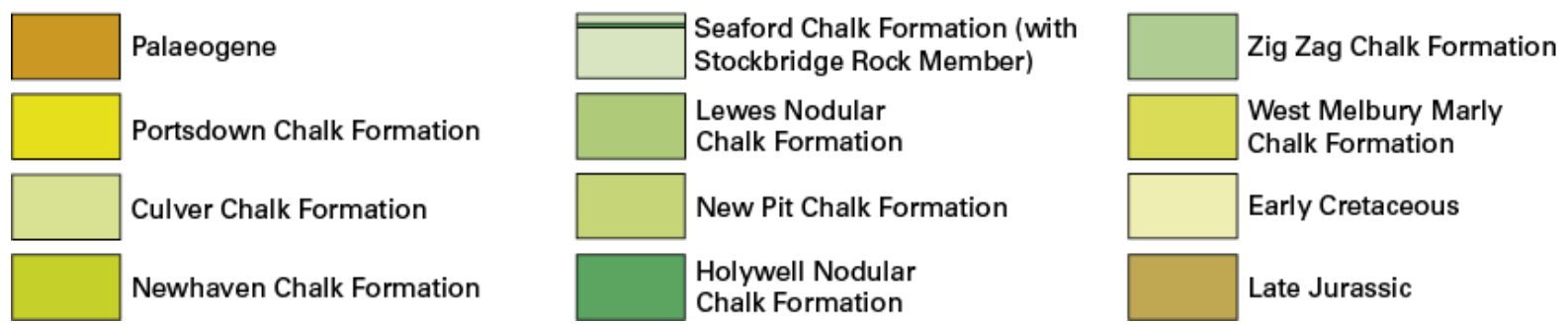

Figs.2c and 2d. Bedrock map of part of the Salisbury district (BGS 1:50 000 scale Geological Sheet 298) using the traditional and modern Chalk lithostratigraphic classifications. The extent of local fault systems, including the Mere Fault, can be better appreciated in 2d. 


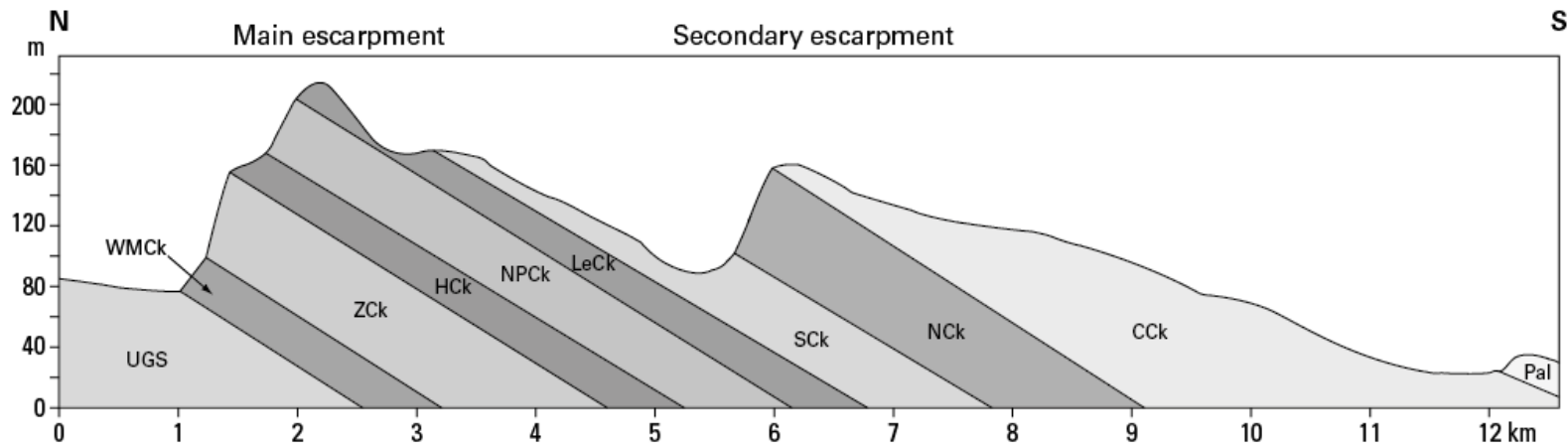

Fig. 3a. Cross-section of the Chalk outcrop. North-south section near the Hampshire-West Sussex border, between Petersfield and Havant.

Pal: Palaeogene; CCk: Culver Chalk; NCk: Newhaven Chalk; SCk: Seaford Chalk; LeCk: Lewes Nodular Chalk; NPCk: New Pit Chalk; HCk: Holywell Chalk; ZCk: Zig Zag Chalk; WMCk: West Melbury Marly Chalk; UGS: Upper Greensand

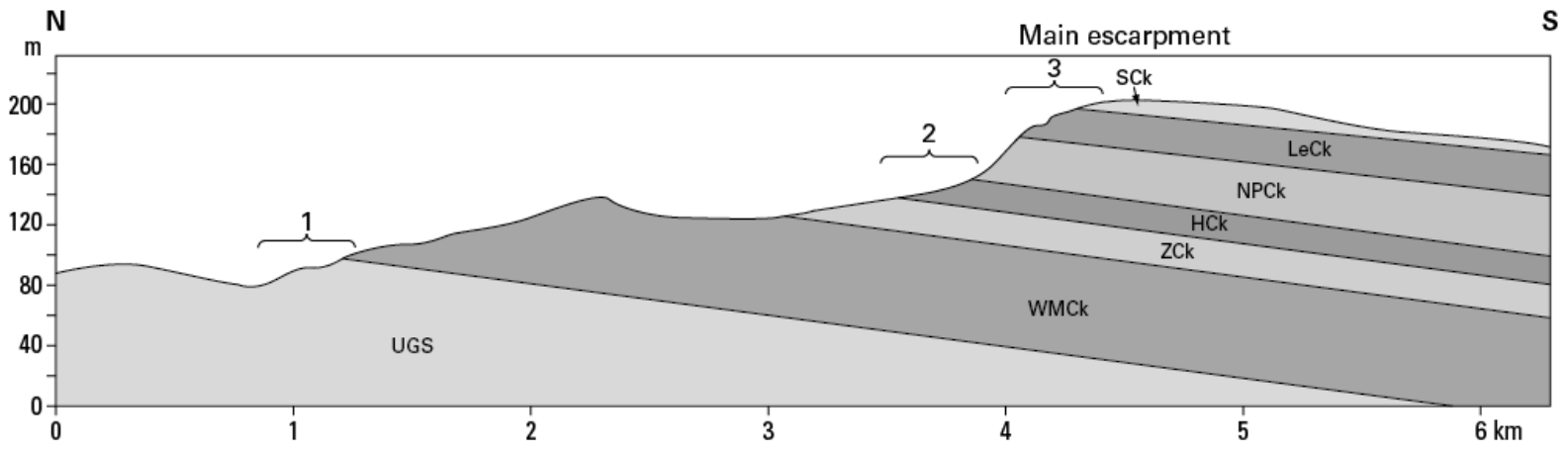

Fig. 3b. Cross-section of the Chalk escarpment. North-south section near Wantage, Berkshire. Symbols as in Fig. 3a. Brackets indicate the extent of profiles shown in Fig. 3c. 

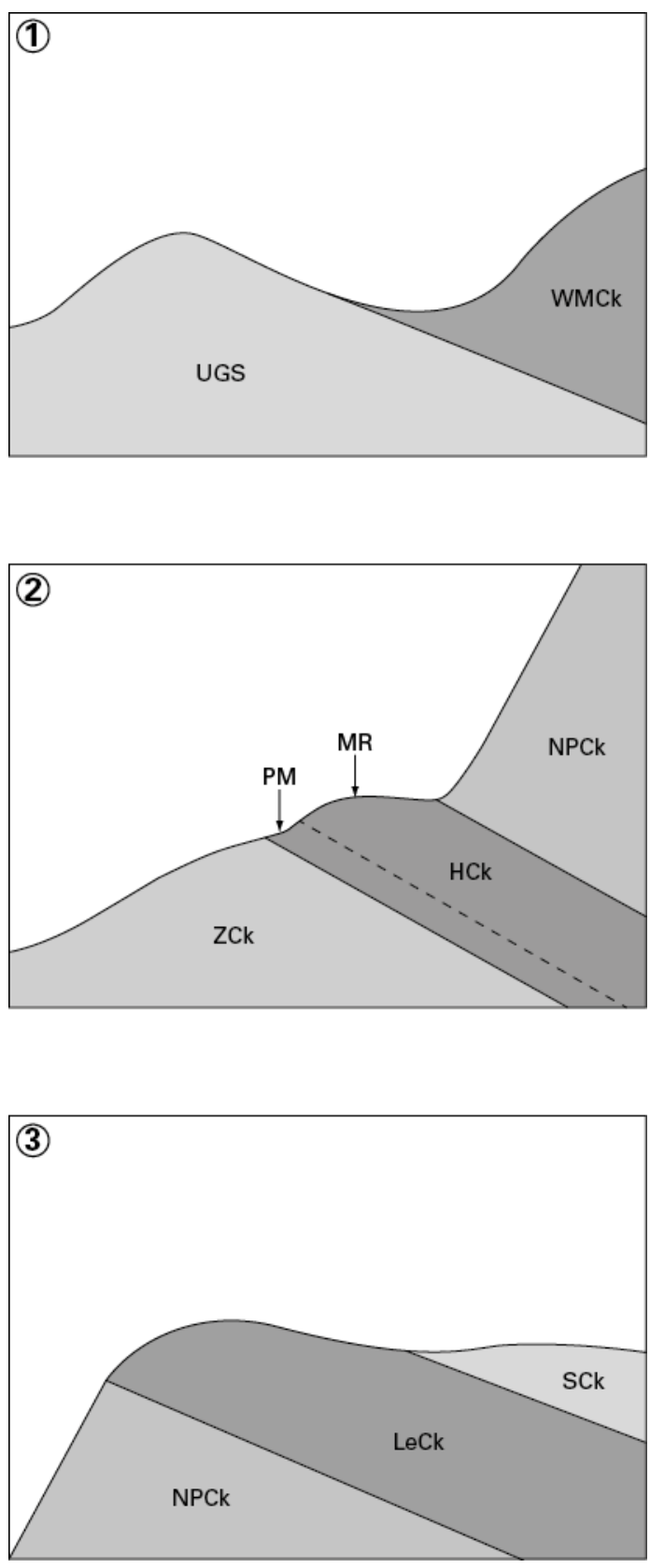

Fig. 3c. Portions of the profile shown in Fig. 3b, exaggerated to emphasize typical relationships between topography and chalk formation. Not to scale. 


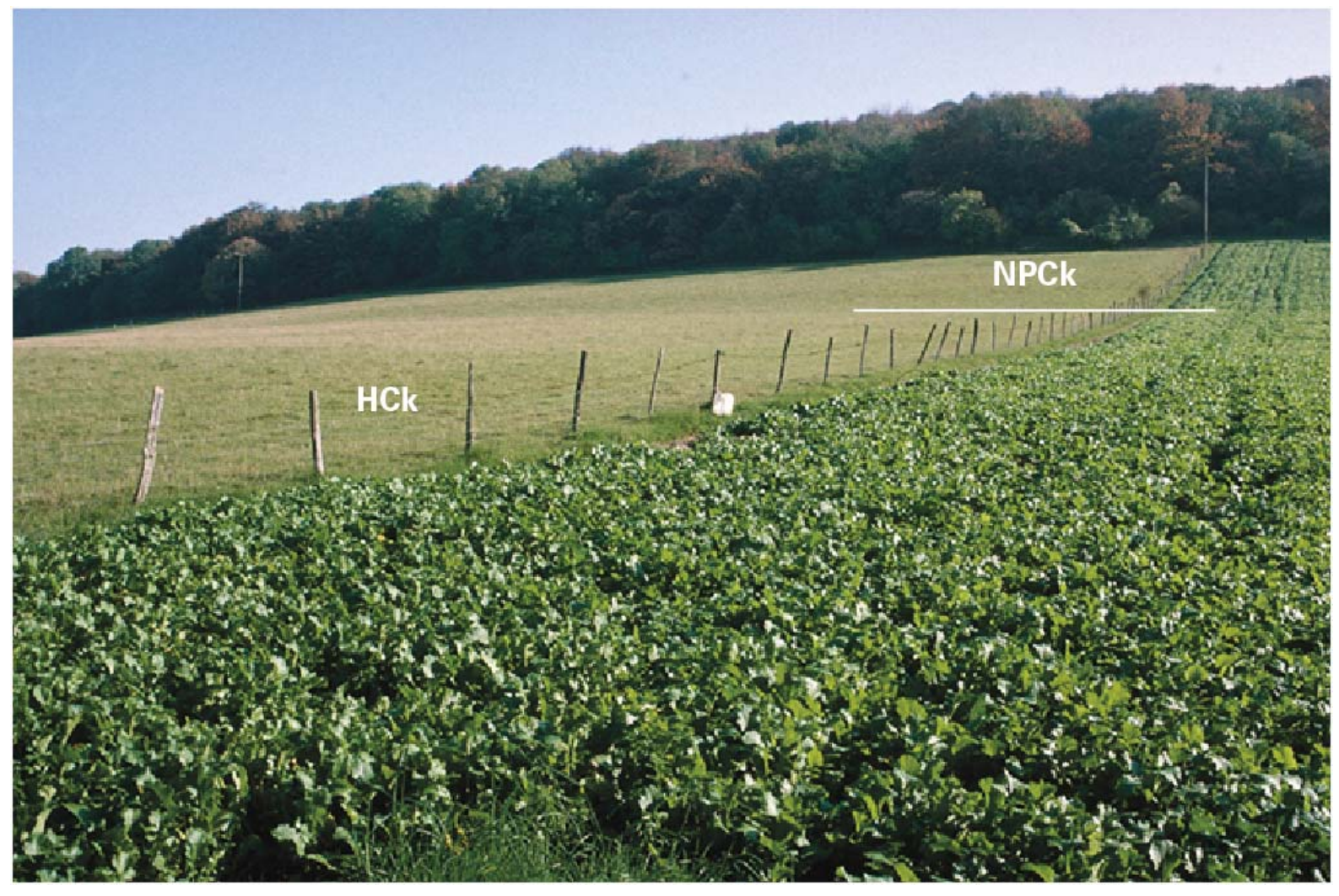

Fig. 4. Typical expression of base of New Pit Chalk Formation in farmland, about 5 km south-southwest of Petersfield, Hampshire (Fig. 1). Base of the New Pit Chalk occurs at the negative break of slope in the middle distance, marked with a white line. Symbols as in Fig. 3. 


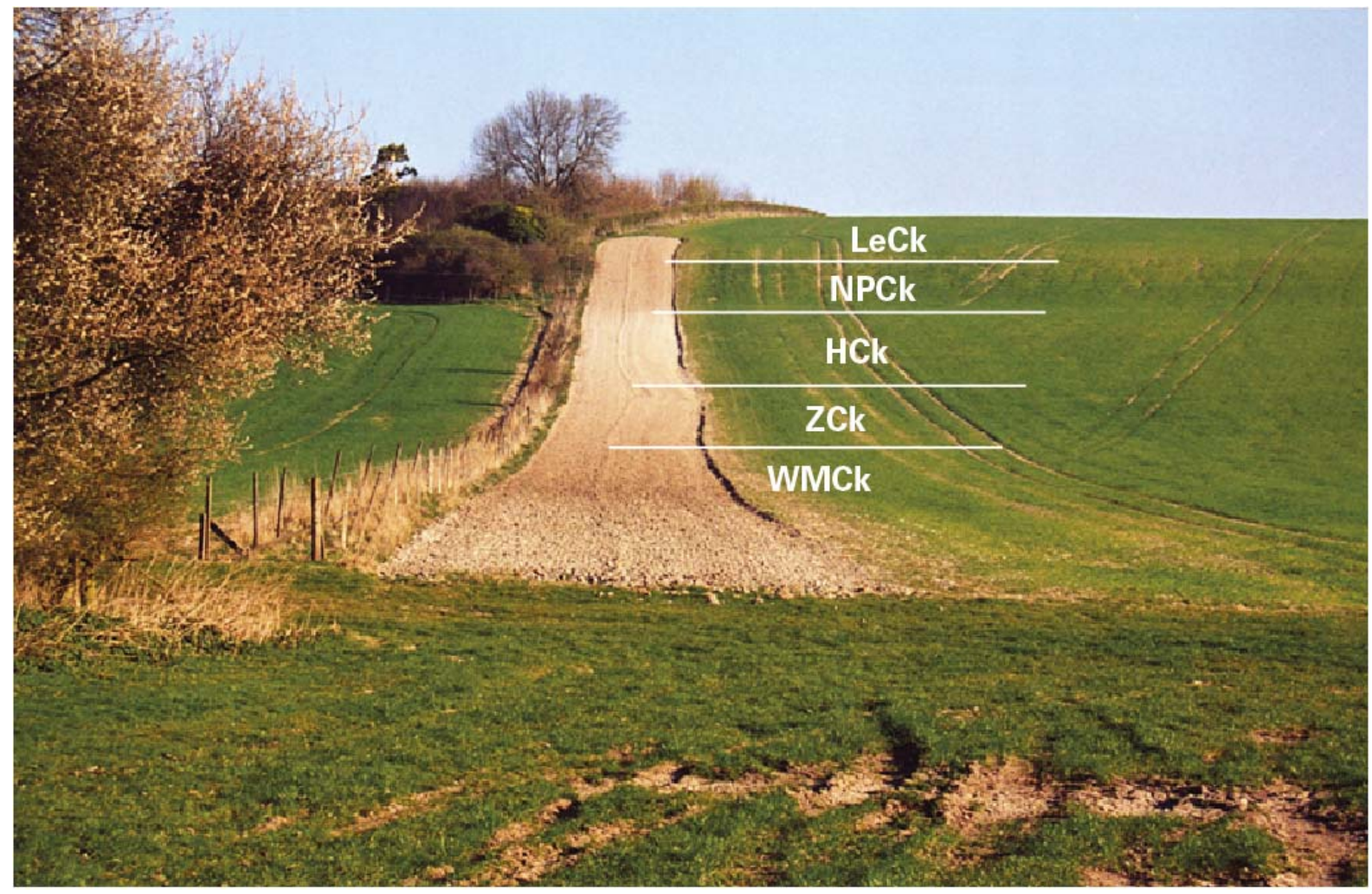

Fig. 5 Expression of chalk formations in farmland, about $5 \mathrm{~km}$ south of Hungerford, West Berkshire (Fig. 1). Symbols as in Fig. 3. The Chalk is dipping away from the camera at about $20^{\circ}$, on the northern limb of a periclinal fold, so that the outcrop widths are reduced. Note changes in soil colour and tractability that accompany topographic breaks of slope, particularly the soft conditions in the foreground (on the West Melbury Chalk), and at the base of the Holywell Chalk (on the Plenus Marls). 